\title{
The Peculiarities of Innovative Development of Resource Regions
}

\author{
Tatiana S. Zimnyakova* \\ Siberian Federal University \\ 79 Svobodny, Krasnoyarsk, 660041, Russia
}

Received 30.05.2017, received in revised form 05.12.2017, accepted 15.12.2017

\begin{abstract}
The transition of the Russian economy to an innovative type of development requires the elaboration and implementation of a systemic state policy aimed at intensifying innovation activities in the regions. However, the resource specialization of the regional economy can have a negative effect on the ability to a sustainable development based on innovation. The purpose of this study is to identify the features of socio-economic development of the regions of resource orientation and identify the factors that contribute to the intensification of innovation activities on their territory. In order to achieve the purpose of the study, the authors did an analysis of the indicators of the socioeconomic development of the resource regions, and identified their common features. In addition, a correlation analysis of the index of innovative activity of resource regions was carried out with a number of factors, such as the level of education of the population, the number of researchers engaged in $R \& D$, and others. The strongest dependence of the innovative performance of the resource region was established with the indicators of scientific potential and volumes of shipped products of manufacturing industries. Thus, for the innovative activity of the resource region, the presence of manufacturing industries with a high level of redistribution in the economy of the region, as well as the accumulated scientific potential of the territory, is essential. The analysis showed that the state policy for the innovative development of resource regions should be based on the support of manufacturing industries that stimulate the creation of innovations and the strengthening of scientific potential.
\end{abstract}

Keywords: natural resource region, curse of natural resource, innovative development.

DOI: 10.17516/1997-1370-0198.

Research area: economics.

Provision of the region with natural resources, as a rule, is regarded as a positive factor for its economic development. However, the presence of structural disparities in the regional economy associated with the dominance of mining activities may pose a threat to the sustainability of development.
The effect of the negative impact of the country's primary specialization on a longterm economic growth has been noted by many researchers and has various names such as "Dutch disease" or "Groningen effect", "resource curse" (Sachs, Warner, 2001), "resource trap" (Guriev, Plekhanov, Sonin, 2010). Researchers

(C) Siberian Federal University. All rights reserved

* Corresponding author E-mail address: tzimnyakova@inbox.ru 
note the following negative aspects, characteristic of resource-rich countries:

- A significant amount of income from natural rent causes macroeconomic instability of resource-like countries and regions: first of all, the inflow of currency from the sale of raw materials causes the strengthening of the national currency, and secondly, the filling of the budget becomes dependent on fluctuations in world prices for resources.

- Excess revenues from the sale of natural resources are distributed extremely obscurely, which imposes social, political and economic constraints on the economic development of countries and regions of resource orientation: the increased political influence of extractive industries allows seeking political and economic decisions in their own interests through ineffectiveness of state institutions.

- Highly profitable extractive industries of resource countries and regions attract investment and human capital, to the detriment of the development of manufacturing industries.

However, recent studies (Guriev, Plekhanov, Sonin, 2010), (Kondrat'ev, 2015) and the specific experience of a number of countries and regions have shown that the resource orientation of the economy is not a "curse", but, conversely, with a competent policy of economic diversification, is able to become an advantage. Examples of countries rich in resources, which, nevertheless, managed to avoid the "resource trap", are the United States, Canada, Norway (Guriev, Plekhanov, Sonin, 2010). Despite the significant volumes of oil and gas production in these countries, their economies demonstrate a steady growth.

Thus, there is no unequivocally proven dependence of resource wealth and low rates of economic growth. One can speak only of a combination of objective effects that are caused by the excessive influence of the resource sector on the sustainability of the socio-economic development of countries.

Macroeconomic effects of the impact of natural resources on the economy of the country as a whole are sufficiently investigated, but the regional aspect of the "resource curse" is studied to a lesser degree.

The Russian economy is territorially heterogeneous. There are significant differences in the socio-economic development of Russian regions. The main objective of this study is to determine whether the resource orientation of the regional economy affects the intensity of innovation development, whether regions are subject to a "resource curse", and what factors can increase the intensity of innovation activity.

In order to analyze the features of the socio-economic development of the raw material territory, it is necessary to determine the classification characteristics, according to which the region can be classified as a resource one.

To determine the specialization of the country's economy as a whole, a number of indicators are used. These are the share of the resource sector in GNP, net exports and employment. The most commonly used indicator is calculated by the structure of exports, since the largest share of products in the export of the country demonstrates its specialization in the world division of labor.

As for regional specialization, the indicators of the share of the resource sector in GRP, in employment are also used to classify the region as a resource one. The figures calculated by the share in the export of products from the region give an incorrect result: according to this indicator, the Russian regions such as Moscow and the Leningrad Region can be included in the resource regions. In addition, other indicators are used in the scientific literature: the ratio of the share of mineral extraction and the share of processing industries (Glazyrina, Klevakina, 
2013), the index of the region's supply with resource and raw materials potential (Polynev, 2010), and the index of relative specialization (Mel'nikova, 2015).

In our opinion, the most indicative is the index of relative specialization. It is calculated as the maximum ratio of the share of extractive industries in the GRP of the region and a similar share in the country's GDP: if for a particular region the maximum value of the index falls on the extractive industry, then the economy of this region is more of a raw material than the economy of the country as a whole (formula 1).

$$
\mathrm{RSI}_{\mathrm{r}}=\max _{j} \frac{S_{j r}}{S_{j}}
$$

where $\mathrm{Sjr}$ is the share of industry $\mathrm{j}$ in GRP, $\mathrm{Sj}$ is the share of industry $\mathrm{j}$ in GDP.
In addition, there are differences in the understanding of what industries are attributed to raw materials ones. In the studies devoted to the "resource curse" (Kondrat'ev, 2015), the sectors that export natural resources, namely, agriculture, fishing, mining, and oil and gas, are regarded as resource ones.

In our study, we will rely on the current All-Russian classifier of economic activities, and we will classify the branches from the section "Extraction of minerals" to the raw materials branches.

There are 16 subjects of the Russian Federation by the relative index of specialization of raw materials. A rather high share of extractive industries (coefficient more than 0.5) is observed in 11 regions, and in 58 subjects it is minimal (see Table 1).

Table 1. Grouping of subjects of the Russian Federation in relation to the relative index of specialization (extractive industry)

\begin{tabular}{|l|c|l|c|}
\hline \multicolumn{1}{|c|}{ Region } & Index & \multicolumn{1}{c|}{ Region } & Index \\
\hline Khanty-Mansiisk Autonomous District & 12,25 & Chechen Republic & 0,13 \\
\hline Nenets Autonomous Okrug & 6,03 & The Republic of Ingushetia & 0,11 \\
\hline Yamalo-Nenets Autonomous District & 4,90 & Primorsky Krai & 0,10 \\
\hline Sakhalin Oblast & 4,38 & Rostov Region & 0,09 \\
\hline Republic Of Sakha (Yakutia) & 4,30 & Republic of Adygea & 0,08 \\
\hline Chukotka Autonomous District & 4,15 & Novgorod Region & 0,07 \\
\hline Orenburg region & 3,29 & Kurgan Region & 0,07 \\
\hline Komi Republic & 3,25 & Altai Republic & 0,07 \\
\hline Tomsk Region & 2,63 & Sevastopol & 0,07 \\
\hline Magadan Region & 2,58 & Altai Territory & 0,06 \\
\hline Kemerovo Region & 2,29 & Lipetsk Region & 0,05 \\
\hline Udmurt Kepublic & 2,26 & Leningrad Region & 0,05 \\
\hline Astrakhan Region & 2,24 & Krasnodar Region & 0,05 \\
\hline Irkutsk Region & 2,17 & Stavropol Region & 0,05 \\
\hline Republic of Tatarstan & 1,93 & Voronezh Region & 0,04 \\
\hline Krasnoyarsk Territory & 1,56 & Kaluga Region & 0,04 \\
\hline Amur Region & 1,47 & Omsk Region & 0,04 \\
\hline Perm Region & 1,46 & Vladimir Region & 0,04 \\
\hline Samara Region & 1,45 & Tula Region & 0,04 \\
\hline Murmansk Region & 1,31 & Pskov region & 0,04 \\
\hline
\end{tabular}


Table 1. Continues

\begin{tabular}{|c|c|c|c|}
\hline Region & Index & Region & Index \\
\hline $\begin{array}{l}\text { Tyumen Region (without Khanty-Mansi } \\
\text { Autonomous District-Yugra and Yamal- } \\
\text { Nenets Autonomous District) }\end{array}$ & 1,29 & Saint Petersburg & 0,04 \\
\hline The Republic of Khakassia & 1,15 & The Republic of Dagestan & 0,04 \\
\hline Zabaikalye Territory & 0,99 & Ryazan Region & 0,03 \\
\hline Belgorod region & 0,94 & Smolensk Region & 0,03 \\
\hline The Republic of Tyva & 0,88 & Ivanovo Region & 0,02 \\
\hline Kursk Region & 0,77 & Kostroma region & 0,02 \\
\hline The Republic of Karelia & 0,74 & Moscow Region & 0,02 \\
\hline Khabarovsk region & 0,48 & North Ossetia Alania & 0,02 \\
\hline Volgograd region & 0,46 & The Republic of Mordovia & 0,02 \\
\hline Kamchatka Krai & 0,44 & Kirov Region & 0,02 \\
\hline The Republic of Buryatia & 0,38 & Bryansk region & 0,01 \\
\hline Republic of Bashkortostan & 0,33 & Oryol Region & 0,01 \\
\hline Kaliningrad Region & 0,31 & Yaroslavl Region & 0,01 \\
\hline $\begin{array}{l}\text { Arkhangelsk Region without } \\
\text { autonomous district }\end{array}$ & 0,30 & Kabardino-Balkaria & 0,01 \\
\hline Ulyanovsk Region & 0,28 & Mari El Republic & 0,01 \\
\hline The Republic of Crimea & 0,26 & Chuvash Republic & 0,01 \\
\hline Saratov Region & 0,22 & Nizhny Novgorod Region & 0,01 \\
\hline Chelyabinsk Region & 0,21 & Penza Region & 0,01 \\
\hline Karachay-Cherkessia & 0,21 & Tambov Region & 0,00 \\
\hline The Republic of Kalmykia & 0,18 & Tver Region & 0,00 \\
\hline Novosibirsk Region & 0,16 & Moscow & 0,00 \\
\hline Jewish Autonomous Region & 0,15 & Vologda Region & 0,00 \\
\hline Sverdlovsk Region & 0,13 & & \\
\hline
\end{tabular}

Calculated by the author according to Rosstat.

For the subsequent analysis, we distinguish two groups of regions - with a high share of extractive industries ("resource regions") and relatively low ("non-resource regions"). The features of the socio-economic development of the two groups are given in the table (see Table 2).

As shown in Table 2, the "resource" Russian regions have the following common features:

- most "resource" regions hav2e territories belonging to the Far North in their structure, characterized by severe climatic conditions of management and residence;
- population density in these regions is lower than the average for "non-resource" regions;

- regional budget, calculated per capita, in "resource" regions significantly exceeds the average data for "non-resource" regions;

- GRP per capita is higher than in nonresource regions;

- financial infrastructure in the "resource" regions is much less developed - the number of regional commercial banks in the "non-resource" regions is on average higher.

Thus, the resource regions of Russia are more often hard-to-reach areas with complex climatic 
Table 2. Average indicators by groups of regions of the Russian Federation, 2015

\begin{tabular}{|c|c|c|c|c|c|c|c|}
\hline Group of regions & 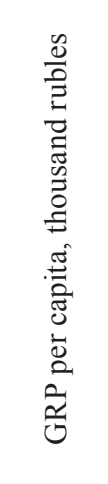 & 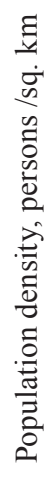 & 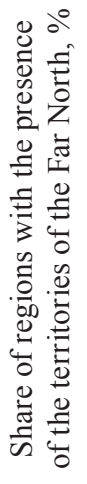 & 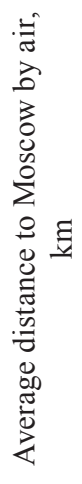 & 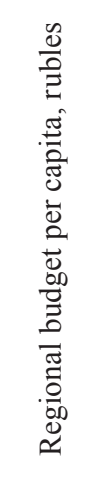 & 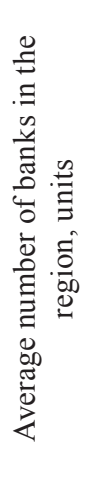 & 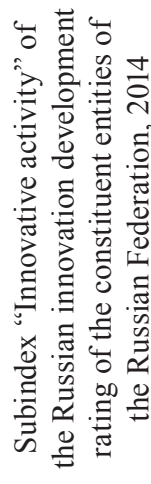 \\
\hline $\begin{array}{l}\text { Resource regions } \\
\text { ( } 27 \text { regions) }\end{array}$ & 566,76 & 3 & 67 & 2925 & 86832 & 4 & 0,280 \\
\hline $\begin{array}{l}\text { Non-resource } \\
\text { regions } \\
\text { (27 regions) }\end{array}$ & 404,52 & 21 & 10 & 1339 & 69175 & 11 & 0,287 \\
\hline
\end{tabular}

Calculated by the author according to the data of Rosstat, Higher School of Economics (Gokhberg. et al., 2016).

conditions, remote from the central regions of the country where the main scientific, financial, and infrastructural resources are concentrated. Despite this, the average value of Subindex "Innovation activity" of the Russian Innovation Development Rating of the Russian Federation constituent entities, calculated annually by the Higher School of Economics, is almost the same for "resource" and "non-resource" regions. This means that, despite the difficult socio-economic and climatic conditions, among the resource regions are territories that are quite successful from the point of view of innovative development.

To determine the factors that affect the "innovation" of the "resource" regions, a correlation analysis was done to establish the dependence of the intensity of innovation activity on the conditions for its implementation. As a measure of innovative performance, the share of innovative goods, works and services in the total volume of shipped goods, works and services was taken.

Thee correlation analysis showed:

- Strong positive relationship of innovation performance with population density (0.7109), the number of regional credit organizations (0.7287), the number of employees engaged in research and development (0.6473);

- average positive correlation of innovative performance with the volume of shipped products of the manufacturing sector (0.5586), internal costs for research and development (0.5321), number of students per 1000 people of the population ( 0.4210$)$, the proportion of the employed population with higher education at the age of 25-64 (0.3304);

- weak positive relationship between innovation performance and investment in fixed assets (0.1411);

- weak negative relationship between innovative performance and distance from Moscow (-0.0885).

Thus, the conducted research confirms the assumption that the most significant factors of the innovative development of the resource region are scientific potential, the development of the financial infrastructure, the availability of manufacturing industry and institutions of higher and vocational education.

An interesting result is demonstrated by a comparative analysis of the two regions - the 
Table 3. Indicators of the Krasnoyarsk Territory and the Republic of Tatarstan, 2015

\begin{tabular}{|l|c|c|}
\hline \multicolumn{1}{|c|}{ Indicators } & $\begin{array}{c}\text { Krasnoyarsk } \\
\text { Territory }\end{array}$ & $\begin{array}{c}\text { Republic of } \\
\text { Tatarstan }\end{array}$ \\
\hline GRP per capita, thousand rubles & 565 & 475 \\
\hline GRP share in the total volume of the country,\% & 2,5 & 2,8 \\
\hline Average annual number of employees in the economy, thousand people & 1439 & 1822 \\
\hline Population density, persons / sq. km & 1,21 & 57,02 \\
\hline $\begin{array}{l}\text { Share of the employed population with higher vocational education at the age } \\
\text { of } 25-64, \%\end{array}$ & 29,1 & 34,5 \\
\hline $\begin{array}{l}\text { Number of students of educational institutions of higher vocational education } \\
\text { per } 1000 \text { people of the population, persons }\end{array}$ & 313 & 422 \\
\hline Number of regional credit institutions & 5 & 22 \\
\hline Share of the employed in manufacturing industries,\% & 2 & 2 \\
\hline Share of processing industries in GRP,\% & 33,5 & 19,1 \\
\hline Share of extractive industries in GRP,\% & 17,5 & 21,6 \\
\hline Number of employees conducted scientific research and development, persons & 7543 & 12708 \\
\hline $\begin{array}{l}\text { Share of innovative goods, works, services in the total volume of goods } \\
\text { shipped, works performed, services, } \%\end{array}$ & 4,0 & 20,4 \\
\hline Presence in the territory of the Far North & да & нет \\
\hline
\end{tabular}

Calculated by the author according to Rosstat.

Republic of Tatarstan and the Krasnoyarsk Territory. Both regions are classified as resource ones, but they differ from other resource regions by a rather high share of extractive industries in the GRP structure. Let us compare some indicators of the two regions (Table 3).

The two regions that make a significant contribution to the GDP of our country that have a commodity orientation of the economy differ significantly in their innovative performance (see the indicator for the share of innovative goods, works and services, Table 3). At the same time, the Krasnoyarsk Territory is the leader of the two regions in terms of the share of manufacturing in the structure of the economy, which should contribute to the intensity of innovation activity. However, this does not happen, because the structure of the manufacturing industries in the two regions is different: in the Krasnoyarsk Territory is dominated by production facilities with a low level of redistribution $(72 \%$ of the volume of shipped production is metallurgical production), while the economy of the Republic of Tatarstan is more diversified: the processing industry is represented by oil refining ( $27 \%$ ), chemistry and petrochemistry $(20 \%)$, production of vehicles $(16 \%)$, production of rubber products (6\%), machine building (4\%), metalworking (4\%), production of electrical equipment $(4 \%)$.

Thus, we can conclude that the "resource curse" is overcome at the meso-level. Resourcerich countries and regions can neutralize the negative manifestations of the "Dutch disease" and provide sustainable economic growth based on innovation. This requires strengthening the scientific and technological potential and supporting the development of manufacturing industries with a high technological level of redistribution. 


\section{References}

Glazyrina, I., Klevakina, E. (2013). Neravenstvo dokhodov, tempy i kachestvo ekonomicheskogo rosta $\mathrm{v}$ regionakh Rossii [Income inequality, rates and quality of economic growth in the regions of Russia]. IPREK SO RAN, ZabGU.

Gokhberg L. et al. (2016). Reiting innovatsionnogo razvitiia sub"ektov Rossiiskoi Federatsii [Rating of Innovative Development of the Russian Federation constituent entities], 4. Moscow, NIU VShE, 248 p.

Guriev, S., Plekhanov, A., Sonin, K. (2010). Ekonomicheskii mekhanizm syr'evoi modeli razvitiia [The Economic Mechanism of the Raw Material Model of Development], In Voprosy ekonomiki [Issues of Economics], 3, 4-23.

Kondrat'ev, V. (2015). Osobennosti resursnoi modeli ekonomicheskogo rosta [Features of the resource model of economic growth], In Problemy teorii i praktiki upravleniia [Problems of theory and practice of management], 6, 20-28.

Mel'nikova, L. (2015). Sovremennaia regional'naia ekonomika: teorii i modeli [Modern regional economy: theories and models]. Novosib. gos. un-t., 304 p.

Polynev, A. (2010). Konkurentnye vozmozhnosti regionov. Metodologiia issledovaniia i puti ee povysheniia [Competitive opportunities of the regions. Research methodology and ways to improve it]. KRASAND, 208 p.

Sachs, J.D., Warner, A.M. (2001). Natural Resources and Economic Development. The curse of natural resources, In European Economic Review, 45, 827-838.

\section{Особенности инновационного развития регионов сырьевой специализации}

Т.С. Зимнякова

Сибирский федеральный университет Россия, 660041, Красноярск, пр. Свободный, 79

\footnotetext{
Переход экономики России к инновациионному типу развития требует разработки и реализаиии системной государственной политики, направленной на интенсификацию инноваџионной деятельности в регионах. Однако сырьевая специализаџия экономики регионов может оказывать негативный эффект на способность к устойчивому развитию, основанному на инновациях. Цель настоящего исследования - выявление особенностей соичиально-экономического развития регионов сырьевой ориентации и определение факторов, способствующих интенсификации инновационной деятельности на их территории. Для достижения иелей исследования был проведен анализ показателей соииально-экономического развития сырьевых регионов, выявлены их общие черты. Кроме того, был проведен корреляционный анализ показателя инновационной активности сырьевых регионов с рядом факторов, таких как уровень образования населения, число исследователей, занятых в НИОКР, и других. Наиболее сильная зависимость инновационной результативности сырьевого региона была установлена с показателями научного потенциала и объемов отгруженной продукции обрабатывающих отраслей. Таким образом, для инноваиионной активности сырьевого региона существенным является присутствие в экономике региона обрабатывающих отраслей с высоким уровнем передела, а также накопленный
} 
научный потенцииал территории. Проведенный анализ показал, что государственная политика по инновационному развитию сырьевых регионов должна основываться на поддержке обрабатывающих отраслей, стимулирующчих создание инновацчй и укрепления научного потеничиала.

Ключевые слова: сырьевой регион, ресурсная ловушка, инновачионное развитие.

Научная специальность: 08.00.00 - экономические науки. 